\title{
ZARZĄDZANIE DLA PRZYWÓDZTWA - IMPLIKACJE EDUKACYJNE DLA SZKOLNICTWA WYŻSZEGO
}

\begin{abstract}
Cybal-Michalska Agnieszka, Zarządzanie dla przywództwa - implikacje edukacyjne dla szkolnictwa wyższego [Management for Leadership - Educational Implications for Higher Education]. Studia Edukacyjne nr 36, 2015, Poznań 2015, pp. 7-17. Adam Mickiewicz University Press. ISBN 97883-232-2958-2. ISSN 1233-6688. DOI: 10.14746/ se.2015.36.1

The article presented in this work is focused on the subject of leadership and management, as well as on the relationships between the two. This discourse requires the inclusion of multicontextual changes of the neo-liberal world, which make leaders face new requirements. The most important of these are: an increasing role of leadership, management for leadership, transformational leadership, styles of management and the ability to manage changes, and finally planning, managing and monitoring careers of organization workers. A subjective overlap of leadership and management constructs will be clearly stressed in the text. Accumulated values that create management and leadership competence and values that are useful in their creation and development contribute to the leadership career capital and management career capital - and perhaps even management for leadership career capital.
\end{abstract}

Key words: management, leadership, career capital, for leadership

Jakość przemian współczesnego świata, że odwołam się do sformułowania I. Wallersteina, „świata jaki znamy” (przy czym, co warto podkreślić, jakość społecznej zmiany w wizji autora to w istocie nawet „koniec świata jaki znamy"1), przyczynia się do zmian w myśleniu o zarządzaniu. Sprowadzając rozważania do stwierdzenia, iż

1 Patrz: I. Wallerstein, Koniec świata jaki znamy, Warszawa 2004, s. 55. 
po raz pierwszy w historii ludzkości pojawiła się realna szansa na to, aby satysfakcja osobista oraz swoboda inicjatywy bezpośrednich wytwórców idei i rzeczy stały się warunkiem należytego funkcjonowania ich warsztatów pracy, a nie tylko treścią utopijnych, proludzkich haseł².

W rzeczy samej, jak podkreśla A. Giddens, fundamentalnym komponentem codziennych aktywności jednostek jest wybór. Intelektualna emancypacja i zdolność do refleksyjnego zachowania, w świecie permanentnej zmiany i różnorodności środowisk społecznych (w które jednostka jest zaangażowana bezpośrednio i pośrednio), umożliwiają wyrażanie osobistej podmiotowości poprzez kreowanie indywidualnych stylów życia i „wybór” tożsamości ${ }^{3}$.

Wielokontekstowe przemiany społeczne, wyrażające się w permanentnej kreacji współczesnego społeczeństwa, specyfika jakościowo nowych przekształceń $w$ relacjach pomiędzy globalnością a lokalnością, społeczeństwem a podmiotem, organizacją a jednostką oraz powiązań między nimi, nie pozostaje bez znaczenia dla jakości rozważań na temat domeny zarządzania i przywództwa. W ciągu ostatnich czterech dekad odnotowano namnażanie się i wielość współwystępujących założeń teoretycznych na temat zarządzania i przywództwa. O wartości debaty na temat teorii kariery ${ }^{4}$ zarządczej i przywódczej świadczy fakt, iż nie jest ona wolna od ożywionego krytycznego oglądu wielości perspektyw teoretycznych. Z podjętych $w$ tym artykule rozważań wynika, iż istnieje potrzeba generowania nowych podejść, które przekroczą granice określane przez cząstkowe paradygmaty tak, aby były one relewantne dla dynamiki przemian współczesnego świata i wyzwań stawianych przed skutecznym przywództwem, a nawet - zarządzaniem dla przywództwa.

Kreowanie strategii zarządzania i stylu zarządzania w świecie zorientowanym na globalną zmianę staje się nie tylko problemem cywilizacyjnym wpływającym na kształt rozwoju organizacji, ale również problemem o wymiarze jednostkowym. Zarządzanie jest najważniejszą częścią każdej organizacji, a wiedza na temat teorii zarządzania jest elementem kluczowym, jeśli mamy odnieść sukces w zarządzaniu czy przywództwie. Wiedza ta odnosi się również do uczelni wyższych, które są przecież organizacjami, a żadna organizacja nie może osiągnąć swoich celów bez skutecznego za-

${ }^{2}$ K. Obuchowski, Człowiek intencjonalny, czyli o tym, jak być soba, Poznań 2000.

${ }^{3}$ R. Whittington, Putting Giddens into Action: Social System and Managerial Agency, Journal of Management Studies, 1992, 6, s. 695-696.

4 Patrz: A. Cybal-Michalska, Młodzież akademicka a kariera zawodowa, Kraków 2013. 
rządzania. $Z$ tego względu zarządzanie uważa się za centrum każdej organizacji ${ }^{5}$.

$\mathrm{U}$ podstaw podjętych $\mathrm{w}$ tym artykule rozważań tkwi założenie o nierozerwalnym związku między przywództwem a zarządzaniem, akcentując, iż

przywództwo i zarządzanie tworzą wzory wzajemnie uzupełniających się zachowań, działań, wiedzy i umiejętności. Należy postrzegać je na kontinuum oddającym realizację funkcji kierowniczej, gdzie obie kategorie, choć ze sobą związane, są jednak odmienne ${ }^{6}$.

Z powyższych ustaleń wynika, że chociaż zarządzanie związane jest ze zdolnością radzenia sobie z kompleksowością, a przywództwo - radzenia sobie ze zmianą, to jak ujmuje to Kotter:

z chwilą, kiedy firmy zrozumieją podstawową różnicę między przywództwem a zarządzaniem, mogą rozpocząć proces szkolenia swoich najlepszych ludzi, który umożliwi im jednocześnie pełnienie obu ról7

Wielu naukowców wciąż zastanawia się nad odpowiedzą na pytanie, czy ktoś rodzi się liderem, czy jest to coś, co można w sobie ukształtować. Czy istotę stanowi wrodzona charyzma czy właściwości, których można się nauczyć?8 Odpowiedzi, co można odczytać z podjętych w pracy rozważań, mogą być zróżnicowane. Aspektem, nad którym ze względu na podjęty w końcowej refleksji wątek warto się zatrzymać, jest szczególne gloryfikowanie przywództwa. W latach 80 . XX wieku badacze problematyki przywództwa i zarządzania opowiadali się za traktowaniem przywództwa jako antidotum na wszelkie niepowodzenia organizacji. Ruch „pozbądźmy się zarządzania”, któremu, jak podkreśla Kożusznik, towarzyszyło hasło: „ludzie nie chcą być zarządzani, lecz chcą, aby im przewodzić" ${ }^{9}$ zaskakuje radykalnością, ale pobudza do myślenia, czy uprawnione jest ukierunkowanie procesu zarządzania dla przywództwa.

${ }^{5}$ Z. Mahmood, B. Muhammad, Z. Bashir, Review of Classical Management Theories, International Journal of Social Sciences and Education, 2012, 2, s. 512.

${ }^{6}$ M.J. Michalak, Przywództwo w zarządzaniu szkoła, Raport Ośrodka Rozwoju Edukacji (tekst dostępny pod adresem internetowym: http://ko.poznan.pl/pub/ftp/kazdy.../ przywodztwo_w_zarzadzaniu_szkola.pdf, dostęp: 8.08.2014), s. 3 .

7 J.P. Kotter, Co właściwie robia przywódcy, Harvard Business Review Polska, 2005, 28, s. $119-120$.

8 G.A. Bohoris, E.P. Vorria, Leadership vs Management. Business Excellence/Performance Management view [w:] Linköping Electronic Conference Proceedings, 2007, s. 1 (tekst dostępny pod adresem internetowym: http://www.ep.liu.se/ecp/026/076/ecp0726076.pdf, dostęp: 18.08.2014), s. 1.

9 M.J. Michalak, Przywództwo w zarzadzaniu szkota, Raport Ośrodka Rozwoju Edukacji, s. $15-18$. 
Krytyczny wobec stawiania na piedestale kwestii przywództwa i wysuwania na pierwszy plan zarządzania Mintzberg stwierdza, że traktując przywództwo jako

funkcję odmienną od zarządzania, nadajemy charakter jednostkowy czemuś, co ma charakter społeczny. Bez względu na to, jak bardzo podkreślamy, że rolą przywódcy jest upodmiotowienie czy uprawomocnienie grupy pracowników, zawsze myślimy głównie o osobie przywódcy - za każdym razem gdy eksponujemy kwestię przywództwa, umniejszamy znaczenie członków grupy i traktujemy ich jedynie jako podwładnych lidera. Osłabiamy w ten sposób także poczucie wspólnoty i przynależności do grupy, jakże ważnych w zespołowym działaniu i niezbędnych w każdej organizacji. Zamiast skupić się na przywództwie, powinniśmy się zająć wspólnotami istot ludzkich, które w naturalny sposób współdziałają przy realizacji celów, a liderów oraz menedżerów powinniśmy traktować jako nieodłączną część tych wspólnot ${ }^{10}$.

We współpracy z menedżerami na różnych poziomach, starsi stażem i bardziej doświadczeni menedżerowie ustalają cele organizacji, a wszyscy którzy w danej organizacji pracują, dokładają starań, aby te cele realizować. Zarządzanie polega na stworzeniu odpowiedniego kontekstu w organizacji, który umożliwi efektywną pracę, a także pomoże organizacji odnaleźć się wśród możliwości i zagrożeń płynących z otoczenia zewnętrznego. Menedżerowie na wszystkich szczeblach kształtują wartości i kulturę organizacji poprzez swoje decyzje i dawanie przykładu innym, chociaż to doświadczeni menedżerowie mają zazwyczaj wyraźny i najbardziej bezpośredni wpływ. Osiągnięcia i sukcesy organizacji są najlepszym dowodem wysiłków i skutecznego zarządzania menedżerów ${ }^{11}$.

Współczesne organizacje (a odnosi się to również do uczelni wyższych) potrzebują zarówno efektywnych liderów, jak i efektywnych menedżerów, aby odnosić sukcesy w działaniu. Oznacza to $z$ jednej strony zorientowanie na zadania, a z drugiej strony - na innowacyjność i wizjonerstwo ${ }^{12}$.

Pojęcia przywództwa i zarządzania mają wiele podobieństw. Jedno i drugie wiąże się z wywieraniem wpływu, pracą z innymi ludźmi i z osiąganiem celu13. Ukształtowanie rzeczonych wymiarów wymaga intencjonalnego i ukierunkowanego procesu ich rozwoju na drodze edukacji. T. Bush wyróżnia następujące modele przywództwa edukacyjnego: mene-

${ }^{10}$ H. Mintzberg, Zarzadzanie, Warszawa 2013, s. 26-27.

${ }^{11}$ K. Darr, Introduction to Management and Leadership Concepts, Principles and Practices, [w:] Essentials of Management and Leadership in Public Health, Eds. R.E., Burke, L.H. Friedman, Ontario-London 2011, s. 8.

12 K.G. Ricketts, Leadership vs Management, [w:] Leadership Behavior, Kentucky 2009, (tekst dostępny pod adresem internetowym: http://www2.ca.uky.edu/agc/pubs/elk1/elk1103/ elk1103.pdf, dostęp: 17.08.2014), s. 1.

13 Tamże, s. 2. 
dżerski, transformacyjny, uczestniczący, transakcyjny, postmodernistyczny, moralny, zorientowany na nauczanie ${ }^{14}$. Jednakże, zmieniające się koncepcje na temat natury zarządzania i przewodnictwa, a także wyzwania związane z tradycyjnymi podejściami do ich rozwoju stanowiły wyraźny przyczynek do pojawienia się wielu nowatorskich trendów w edukacji odnośnie zarządzania i przywództwa. Williams zauważa wzrost popytu na studia podyplomowe i kursy doskonalące znajdujące się w ofercie uniwersytetu. Hirsh i Carter zauważają wyraźne przejście do bardziej elastycznych oraz dopasowanych do wymagań jednostek i organizacji propozycji szkoleń. Taka zmiana wymaga odwrócenia wielu tradycyjnych edukacyjnych priorytetów: od teorii do praktyki, od części do systemu, od etapów i ról do procesów, od wiedzy do nauki, od wiedzy indywidualnej do partnerstwa oraz od analizy do refleksyjnego zrozumienia. Podstaw tych zmian należy upatrywać w przełomie paradygmatycznym, wyznaczającym nową jakość myślenia o istocie zarządzania i przywództwa oraz zmianę perspektyw filozoficznych na temat roli zarządzania i przywództwa. Metarefleksja ma swoje odzwierciedlenie w praktyce i odwołuje się do takich kwestii, jak: skuteczne menedżerstwo, większa konkurencyjność organizacji. Mole stosuje wyraźne rozróżnienie pomiędzy pojęciami: szkolenie $\mathrm{w}$ temacie zarządzania, edukacja i rozwój. W ujęciu teoretyka, trening koncentruje się na obecnej pracy pracownika; edukacja skupia się na przyszłej pracy, natomiast rozwój - na organizacji. Współczesny trend koncentruje się na edukacji, ale przede wszystkim na rozwoju. Programy rozwojowe przygotowują jednostki do zmiany i pójścia w nowym kierunku, który może być spowodowany zmianami oraz rozwojem $\mathrm{w}$ organizacji. Bush i Glover dokonali podobnego rozróżnienia i zrealizowali przegląd teorii na temat rozwoju przywództwa, identyfikując trzy kontrastujące modele rozwoju przywództwa. Każde z wyróżnionych podejść pozwala na zidentyfikowanie względnych wartości i słabości każdego $\mathrm{z}$ nich, jak również reprezentuje znaczące filozoficzne spojrzenie na naturę zarządzania i przywództwa w organizacjach. Wyróżnione modele to: model "naukowy” (techniczny), który polega na szkoleniu w celu osiągnięcia jasno zdefiniowanych celów; model "humanistyczny" skupiający się na ludziach oraz na strategicznie zaplanowanych transformacyjnych interakcjach oraz model „pragmatyczny” (racjonalny), który koncentruje się na projektach, kładąc nacisk na pilne potrzeby jednostek oraz grup. Aby lepiej zrozumieć kształcenie $\mathrm{w}$ temacie zarządzania, Holman cytuje cztery powracające motywy $\mathrm{w}$ debatach na temat celu, natury i wartości edukacji na poziomie

14 Patrz: Z. Melosik, Systemy ksztatcenia i doskonalenia kadry kierowniczej w krajach Unii Europejskiej i Stanach Zjednoczonych, Warszawa 2014, s. 6. 
wyższym, uzupełniając o piąty element. Obok motywu epistemologicznego (odzwierciedlającego założenia na temat natury poszukiwanej wiedzy), motywu pedagogicznego (wyrażającego naturę procesu uczenia się, zamierzonych wyników i metod nauczania), a także motywu organizacyjnego (odnoszącego się do zarządzania i organizacji edukacji), jak również motywu społecznego (odzwierciedlającego rolę edukacji w społeczeństwie), wymienia zarządzanie, odnosząc się tym samym do koncepcji na temat natury praktyk zarządzania. Odwołując się do różnorodności powyższych motywów, nie zaskakuje fakt, że pojawiły się jakościowo różne podejścia do tematu rozwoju zarządzania i przywództwa. Holman rozwijając swoje podejście, zidentyfikował cztery współczesne modele edukacji zarządzania (patrz tab. 1), dochodząc do wniosku, że akademicki liberalizm (ważny ze względu na nadmierne poleganie na teorii) i praktyczne szkolenia zawodowe (ważne ze względu na nadmierne poleganie na działaniu) są pożądane jeśli mamy wykształcić praktykujących menedżerów. Ponadto proponuje, aby to empiryczny liberalizm oraz empiryczne / krytyczne podejścia kształtowały menedżerów, którzy będą $\mathrm{w}$ stanie sprostać prospektywnym zmianom oraz potrzebom organizacji i społeczeństwa. Empiryczna pedagogika promuje uczenie się i rozwój $\mathrm{w}$ naturalnym środowisku w pracy oraz wskazuje na umiejętność poradzenia sobie ze złożoną naturą rzeczywistych praktyk zarządzania.

Tabela 1

Współczesne modele edukacji zarządzania

\begin{tabular}{|l|l|}
\hline $\begin{array}{l}\text { Akademicki } \\
\text { liberalizm }\end{array}$ & $\begin{array}{l}\text { Zakłada, że edukacja zarządzania powinna przede wszystkim doty- } \\
\text { czyć podążania za obiektywną wiedzą na temat zarządzania. W ten } \\
\text { sposób podejście to stara się szerzyć ogólne zasady i teorie, które da } \\
\text { się zastosować w relatywnie naukowy i racjonalny sposób. Z tej per- } \\
\text { spektywy, celem rozwoju zarządzania powinno być stworzenie "na- } \\
\text { ukowca zarządzania”, który jest w stanie przeanalizować i zastoso- } \\
\text { wać teoretyczne zasady. Główne metody nauczania to wykłady, } \\
\text { seminaria, badanie przypadków i eksperymenty. }\end{array}$ \\
\hline $\begin{array}{l}\text { Empiryczny } \\
\text { liberalizm }\end{array}$ & $\begin{array}{l}\text { Ma podobne do akademickiego liberalizmu założenia, ale większą } \\
\text { doświadczeń w dziedzinie zarządzania, aniżeli praktyk teoriopo- } \\
\text { znawczych. Głównym celem tego podejścia jest stworzenie "myślacego } \\
\text { praktyka", wyposażonego w odpowiednie praktyczne umiejętności } \\
\text { i wiedzę oraz zdolność do dostosowywania się i uczenia się z zaistnia- } \\
\text { łej sytuacji. Główne metody nauczania to praca grupowa, uczenie się } \\
\text { poprzez działanie oraz rozwój samego siebie. }\end{array}$ \\
\hline $\begin{array}{l}\text { Empiryczne } \\
\text { szkolenia } \\
\text { zawodowe }\end{array}$ & $\begin{array}{l}\text { Wynika z ekonomicznych i organizacyjnych obaw, że należy wyposa- } \\
\text { żýnenedżerów w odpowiednie umiejętności i wiedzę wymaganą } \\
\text { przez organizację i taka jest właśnie rola edukacji w zakresie zarzą- } \\
\text { dzania. Celem tego podejścia jest stworzenie „kompetentnego menedże- }\end{array}$ \\
\hline
\end{tabular}




\begin{tabular}{|l|l|}
\hline & $\begin{array}{l}r a^{\prime \prime}, \text { wyposażonego w niezbędne interpersonalne i techniczne kompe- } \\
\text { tencje wymagane przez organizacje. }\end{array}$ \\
\hline $\begin{array}{l}\text { Pa na celu, jak podkreśla Holman, wyzwolenie menedżerów i innych } \\
\text { empiryczne/ } \\
\text { krytyczne } \\
\text { pracowników organizacji z opresji i alienacji. W tym sensie, podejście } \\
\text { to ma wiele wspólnego z empirycznym liberalizmem, chociaż domaga } \\
\text { się ono bardziej krytycznego poziomu refleksji, która umożliwia jed- } \\
\text { nostkom stanie się bardziej refleksyjnymi w aspekcie posiadanej wie- } \\
\text { dzy i jakości działań, także w celu sformułowania praktycznych } \\
\text { i emancypacyjnych form działania. Stąd główną myślą tego podejścia } \\
\text { jest stworzenie "krytycznego praktyka”, będącego w stanie stawić czoła } \\
\text { i rozwinąć nowe sposoby działania. Główne metody nauczania to } \\
\text { podejścia, które bazują na krytycznym uczeniu się poprzez działanie } \\
\text { oraz na krytycznej refleksji. }\end{array}$ \\
\hline
\end{tabular}

Źródło: R. Bolden, Trends and Perspectives in Management and Leadership Development, Business Leadership Review, 2007, IV, s. 2-5.

W kontekście podjętej debaty na temat celu edukacji w dziedzinie zarządzania i przywództwa wyraźnie daje się zauważyć trend, w którym odchodzi się od tradycyjnych formalnych programów na rzecz elastycznych i empirycznych inicjatyw. Weindling zauważył, że zadziwiająco niewiele programów opiera się na wyraźnych teoriach zarządzania i praktykach przywództwa, a Hirsch i Carter z kolei dostrzegają trzy istotne napięcia, którym muszą stawić czoła uczący zarządzania. Po pierwsze, wraz z modularyzacją formalnych programów mamy do czynienia z coraz większą presją, aby programy kształcenia były przystosowane i użyteczne dla liderów i menedżerów na każdym szczeblu organizacji. Po drugie, wzrost zindywidualizowanego kształcenia, takiego jak coaching, czy ocena 360 stopni, stanowi poważne wyzwanie ze względów temporalnych - potrzebna jest większa ilość czasu dla dopasowania i wsparcia określonego świadczenia. Po trzecie, wraz z zanikaniem tradycyjnych struktur kariery i zatrudnienia na całe życie, menedżerowie otrzymują niewiele wsparcia w kwestii długoterminowego planowania swojej kariery. Stąd daje się zauważyć, że istnieje szereg czynników wpływających na obecny zasięg oraz wymiar zarządzania i przywództwa. Niektóre z nich są bezpośrednio związane z jakością i rozwojem edukacji zarządzania. Inne z kolei mają charakter konceptualny i odnoszą się do założeń, celów edukacji, natury zarządzania i przywództwa oraz relatywnego charakteru relacji jednostka - grupa. Każda z tych kwestii ma duży stopień złożoności, ale bez świadomości podstawowych problemów leżących u podstaw założeń, będzie trudno wybrać efektywne podejście do rozwoju przywództwa ${ }^{15}, \mathrm{w}$ tym również zarządzania dla przywództwa.

15 R. Bolden, Trends and Perspectives in Management and Leadership Development, Business Leadership Review, 2007, IV, s. 2-5. Podkreśla się istnienie prawdy, że zbiera się to, co się za- 
Liczba rozwojowych i edukacyjnych inicjatyw przywodzi na myśl refleksję na temat organizacyjnego wymiaru edukacji. Gosling i Mintzberg zaproponowali siedem głównych założeń, na których powinno opierać się prawdziwe zarządzanie. Odnosząc się do zagadnienia edukacji zarządzania, badacze zwracają uwagę na następujące fakty: a) edukacja zarządzania powinna ograniczyć się do praktykujących menedżerów, wybieranych na podstawie ich efektywności; b) edukacja zarządzania i praktyka powinny przebiegać równolegle oraz być zintegrowane; c) edukacja zarządzania powinna wykorzystywać pracę i doświadczenie życiowe; d) w edukacji zarządzania kluczową kwestią jest roztropna refleksja; e) rozwój zarządzania powinien przynieść efekt $\mathrm{w}$ postaci rozwoju organizacji; f) edukacja zarządzania powinna być interaktywnym procesem; g) każdy wymiar edukacji powinien ułatwiać uczenie się. Implikacje płynące $\mathrm{z}$ wyróżnionych zasad są wielorakie dla obu stron, zarówno dla tych, którzy uczestniczą w rozwoju zarządzania i przywództwa, jak i tych, którzy tworzą ofertę edukacyjną i ją dostarczają. Na szczególną uwagę zasługuje wzajemne oddziaływanie pomiędzy doświadczeniem, teorią, praktyką a refleksją, pomiędzy rozwojem jednostki a rozwojem organizacji, a także pomiędzy dostawcą oferty a uczestnikiem. Zjawisku zarządzania można przyglądać się z wielu perspektyw i każda zakłada procesualny charakter. Podobnie postrzegany jest fenomen przywództwa (przywództwo nie jest czymś czego nauczasz albo czego się uczysz - jest to proces uczenia się). Procesualny kontekst pozwala na istnienie możliwości kreowania działań na rzecz zarządzania swoją karierą i monitowania swojej kariery dla przywództwa. Wyróżnione podejście wskazuje na nową jakość partnerstwa pomiędzy firmami a szkołami zarządzania i biznesu, które wzbogaci dyskurs na temat zarządzania rozwojem organizacji po obu stronach. W tym sensie rozwój przywództwa, zwłaszcza możliwość cofnięcia się i ponownego spojrzenia na praktykę, powinien być częścią składową wszystkich aspektów funkcjonowania organizacji, a więc zarządzania organizacją. Aby upewnić się, że czerpiemy jak najwięcej z rozwoju przywództwa, zaleca się krytyczne ocenianie aktualnie obowiązującej koncepcji przywództwa i uczenia się w ramach swojej organizacji, myślenia o potrzebach rozwojowych zarówno jednostek, jak i organizacji oraz diagnozowanie, jak zmieniają się potrzeby rozwojowe biorąc pod uwage dynamikę czasową. Oznacza to również rozpoznanie różnych opcji i ofert rozwoju, płynących od różnych dostawców wiedzy i negocjowanie dopasowania programów kształcenia do wymagań słuchaczy tak, aby zmaksymali-

siało, podając za przykład sytuację, że jeśli rozwój i system nagród sprzyja wkładowi jednostki, zamiast zaangażowaniu ogółu, wówczas trudno będzie stworzyć kulturę, która zachęca do współpracy i wspólnego przywództwa. 
zować korzyści uczenia się i przenieść nabytą wiedzę do miejsca pracy. Jakość procesów zarządzania, poprzedzających i następujących po działaniach mających na celu edukację i rozwój, jest zapowiedzią tego, czy nowo nabyte kompetencje zostaną docenione i wykorzystane w praktyce. Nie bez znaczenia jest przyglądanie się innym systemom i procesom organizacyjnym, zwłaszcza strategii HR. Perspektywa jednostkowa nakazuje również dopuszczenie do siebie "głosu wewnętrznego" i rozpoznanie oraz przepracowanie psychologicznych barier, które utrudniają efektywne przywództwo, takich jak: niska samoocena, brak pewności siebie, lęk przed porażką lub odtrąceniem, „zawężenie” poznawcze i negatywne skutki stresu. Radzenie sobie z wyróżnionymi problemami obejmuje takie techniki, jak: wzmocnienie, psychologiczna rekonstrukcja, rozwój umiejętności społecznych. Postuluje się oparcie się na mocnych stronach i szukanie sposobu na radzenie ze słabościami. Kluczem do odniesienia sukcesu w byciu liderem nie jest zapełnianie luk $\mathrm{w}$ kompetencjach, ale wzmacnianie $\mathrm{w}$ sobie swoich silnych stron i wyjątkowości. Gosling i Murphy mówią o znaczeniu ciągłości w procesie zmiany. Poczucie ciągłości własnego Ja mimo upływu czasu stanowi jedną z najważniejszych składowych tożsamościowych podmiotu. Mogą pojawić się transformacyjne zmiany, ale w większości przypadków sytuacja wymaga rozważnego podejścia i korzystania z uwewnętrznionych umiejętności jednostkowych i organizacyjnych. Podkreśla się znaczenie, rolę oraz wpływ kultury i kontekstu organizacji dla zachęcenia, zmotywowania i zainspirowania ludzi do pracy $\mathrm{w}$ danym zawodzie, stosując odpowiedni styl komunikacji dla zaprezentowania jej celów i wartości. Na tematykę przywództwa i rozwoju organizacji należy patrzeć długoterminowo, uświadamiając sobie jego procesualny charakter. Warto w tym kontekście zastanowić się, jak różne działania edukacyjno-rozwojowe wpisują się w bieg życia oraz kariery jednostek i organizacji16.

O wartości debaty na temat przywództwa w aspekcie edukacyjnym świadczą rozważania na temat krystalizowania się tożsamości lidera. Głównymi kategoriami tej ugruntowanej teorii były poszczególne etapy tożsamości lidera. Proces rozwoju tożsamości przywódcy to proces przejścia przez kolejne etapy rozwoju na drodze kontaktu z grupą, która zmienia spojrzenie na siebie, na innych, poszerza spojrzenie na temat przywództwa. Wśród zwolenników wpływów rozwojowych ilustruje się na podstawie badań empirycznych następujące etapy rozwoju tożsamości lidera: świadomość, eksploracja (zaangażowanie), lider zidentyfikowany, zróżnicowane przywództwo, generatywność, integracja (synteza). Pierwszym etapem jest zauważenie,

16 Tamże, s. 9-11. 
że liderzy istnieją. Drugi etap stanowi czas celowego zaangażowania, doświadczeń grupowych i wywiązywania się z odpowiedzialności. Jest to faza rozwoju umiejętności, włącznie z obserwacją modeli przywództwa. Na trzecim etapie uczestnicy zdają sobie sprawę, że grupy składają się z liderów i naśladowców. Na tym etapie wyłania się jeden lider - ten lider i on odpowiada za wyniki grupy. Na czwartym etapie ma miejsce postrzeganie roli pozycyjnego lidera jako podmiotu łączącego społeczność i kształtującego kulturę grupy. Na piątym etapie doświadcza się aktywizmu przywódczego oraz widać dążenie do zmiany, wzajemne powiązania, akceptowanie odpowiedzialności i troskę o rozwój innych. Ostatnim etapem jest aktywne zaangażowanie $w$ przywództwo. Postrzeganie przywództwa jako codziennego procesu, jako wymiaru tożsamości jednostki pewnej siebie, dążącej do kongruencji i wewnętrznej integralności. Przywódca rozumie złożoność organizacji i wykazuje myślenie systemowe. Inwestycja w przywództwo, zinternalizowane jako cecha osobowości, sprawia, że lidera charakteryzuje giętkość poznawcza i zdolność do wykorzystania swojej wiedzy i umiejętności w nowych kontekstach, postrzeganie przywództwa jako codzienność 17 .

Ciekawy poznawczo kontekst dla refleksyjnego odniesienia się do podjętego w temacie zagadnienia ilustruje pogląd Fentona:

liderzy wyróżniają się tym, że są inni. Kwestionują założenia i są podejrzliwi wobec tradycji. Szukają prawdy i podejmują decyzje opierając się na faktach, a nie uprzedzeniach. Preferują innowacje ${ }^{18}$.

Jeśli założymy, że autor odnosił się w swojej opinii tylko do liderów, to tym samym należałoby uznać, iż menedżerowie niekoniecznie poszukują prawdy i są innowacyjni, ale także chętnie trzymają się tradycji. Duch czasu nie pozwala nam na tak duże uproszczenie. Seiling, omawiając warunki konieczne do tego, by menedżer stał się inspiratorem zmian, wymienia cechy, które można przypisać przywódcy. Należą do nich umiejętności w takich obszarach, jak:

dostrzeganie odmiennej rzeczywistości, wyrażanie tego, co nie wypowiedziane, podważanie oraz podejmowanie ogromnego ryzyka bycia postrzeganym jako osoba pozbawiona realizmu - a nawet mało wiarygodna - $\mathrm{z}$ powodu chęci stworzenia całkowicie nowego środowiska pracy ${ }^{19}$.

17 S.R. Komives i in., Developing a Leadership Identity: A Grounded Theory, Journal of Student Development, 2005, 46, 6, s. 605-607.

18 M. Bhamani, T. Rose, L. Bramble, The Difference Between Leadership and Management Schools of Thought, Athabasca University 2012, s. 14.

19 T. Brown, Nowy rodzaj pracownika wymaga nowego rodzaju menedżera [w:] Zarzadzanie kariera, Warszawa 2006, s. 45-46. 
Złożoność uwarunkowań przywództwa i zarządzania znajduje zatem zastosowanie $w$ odniesieniu do nowych idei i trendów wskazujących na relacyjny charakter omawianych konstruktów. Dyskurs na temat przywództwa i zarządzania oraz relacji między przywództwem a zarządzaniem nakazuje uwzględniać wielokontekstowe zmiany neoliberalnego świata, które stawiają przed liderami nowe wymagania.

\section{BIBLIOGRAFIA}

Bhamani M., Rose T., Bramble L., The Difference Between Leadership and Management Schools of Thought, Athabasca University 2012.

Bohoris G.A., Vorria E.P., Leadership vs Management. Business Excellence/Performance Management view [w:] Linköping Electronic Conference Proceedings, 2007, (tekst dostępny pod adresem internetowym: http://www.ep.liu.se/ecp/026/076/ecp0726076.pdf, dostęp: 18.08.2014).

Bolden R., Trends and Perspectives in Management and Leadership Development, Business Leadership Review, 2007, IV.

Brown T., Nowy rodzaj pracownika wymaga nowego rodzaju menedżera, [w:] Zarządzanie kariera, Warszawa 2006.

Cybal-Michalska A., Młodzież akademicka a kariera zawodowa, Kraków 2013.

Darr K., Introduction to Management and Leadership Concepts, Principles and Practices, [w:] Essentials of Management and Leadership in Public Health, Eds. R.E., Burke, L.H. Friedman, Ontario-London 2011.

Komives S.R., Owen J.E., Longerbeam S.D., Mainella F.C., Osteon L., Developing a Leadership Identity: A Grounded Theory, Journal of Student Development, 2005, 46, 6.

Kotter J.P., Co właściwie robia przywódcy, Harvard Business Review Polska, 2005, 28.

Mahmood Z., Muhammad B., Bashir Z., Review of Classical Management Theories, International Journal of Social Sciences and Education, 2012, 2.

Melosik Z., Systemy ksztatcenia i doskonalenia kadry kierowniczej w krajach Unii Europejskiej i Stanach Zjednoczonych, Warszawa 2014.

Michalak M.J., Przywództwo w zarządzaniu szkoła, Raport Ośrodka Rozwoju Edukacji (tekst dostępny pod adresem internetowym: http://ko.poznan.pl/pub/ftp/kazdy.../przywo dztwo_w_zarzadzaniu_szkola.pdf, dostęp: 8.08.2014).

Mintzberg H., Zarządzanie, Warszawa 2013.

Obuchowski K., Człowiek intencjonalny, czyli o tym, jak być soba, Poznań 2000.

Ricketts K.G., Leadership vs Management, [w:] Leadership Behavior, Kentucky 2009, s. 1 (tekst dostępny pod adresem internetowym: http://www2.ca.uky.edu/agc/pubs/elk1/ elk1103/elk1103.pdf, dostęp: 17.08.2014).

Wallerstein I., Koniec świata jaki znamy, Warszawa 2004.

Whittington R., Putting Giddens into Action: Social System and Managerial Agency, Journal of Management Studies, 1992, 6. 